\title{
ADOPTING AND ADAPTING HERMENEUTIC METHOD WITHIN TRANSLATION STUDIES
}

\author{
INGRIDA VAŇKOVÁ
}

\begin{abstract}
The present study focuses on the application of the hermeneutic method within translation process. The examination of the issue draws on the already established concepts of translational hermeneutics, which consider this method as a part of the initial phase of the translation activity. However, the study presents the approach according to which hermeneutic activity is present throughout whole translation process. The author thus examines deployment of Ricoeur's hermeneutic concept of interpretation and understanding of the complex translation activity. Finally, a new hermeneutic-pragmalinguistic conceptualization method is introduced applying the hermeneutic approach within the complex translation process. It is noted that on a semantic level the person who pronounces the word I, which is associated with a specific name, forms personal identity. At the pragmatic level, the meaning of the word I become contextually dependent on the discourse in which it is constantly formed. On the borderline between semantics and pragmatics, a person becomes a reflexive Self, capable of hermeneutical activity of understanding. The author focuses on Ricoeur's research, which defines language as an objective system and / or code and discourse. He also argues that language as a code is collective in that it exists as a set of parallel rules (synchronous system) and is anonymous in the sense that it is not the result of any intention. The language is not conscious in terms of structural or cultural unconsciousness.

The author focuses on the stages of hermeneutic activity. This indicates that the first step reveals the essence of interpretation as an important part of the hermeneutical method, which is a dynamic process that includes a non-methodological moment of understanding and a methodological moment of explanation. Characterizes the second stage of hermeneutic activity it is the stage of configuration. That is, the stage of conceptualizing meaning in language. The third stage, that is, the stage of refiguration, is a complete understanding of the discourse and its interpretation. Hermeneutic activity is fully realized in reading, which represents the space between pragmatics and semantic structure. This phenomenon is described as the stage where a person operates with all their knowledge, pragmatic language and experience, not yet structured to solve one particular cognitive-reflexive task. With regard to the thematic and non-thematic cognitive abilities of each person, the translator, as a professional user of at least two languages, has a cognitive-reflexive knowledge in which at least two language cultures interrelate and intersect. It is vaccinated that, at the interlingual and interlingual levels of hermeneutic activity (in interpretation and understanding), an individual not only uses language but also changes and transforms it.
\end{abstract}

Keywords: Discourse, Hermeneutics, Interpretation, Text, Translation, Hermeneuticpragmalinguistic Conceptualization Method. 


\section{INTRODUCTION}

The identification of the basic issues examined within translation studies, such as the issues of equivalence, transfer of meaning and form, the function of the translation and its cultural appropriateness, has initiated the development of numerous approaches within this field varying from traditional approaches drawing on the concept of equivalence to approaches building on the Skopos theory. In addition to the confrontation of numerous approaches, the incorporation of other social and human sciences into translation studies can be observed, as the focus of research is the person of a translator. A translator becomes the focal point of the translation process, and the central issues dealt with by translation studies are thus explored with regard to a translator's cultural and linguistic anchorage in two different lingua-cultures and the issue of hermeneutic understanding as a basic translation tool within translation as intercultural communication. To clarify the issue of the function of hermeneutic understanding, translation studies draw on the current philosophy, which is characterized by prioritizing the issues of human linguistic anchorage and human understanding of the whole extralinguistic reality including ones existence.

\section{RESUlTS AND DisCUSSION}

Although the idea of applying the hermeneutic method in translation studies has emerged some time ago, its full adaptation to translation activity is not yet fully reflected in this field. Stolze (2011) considers hermeneutic understanding to be one of the basic priorities of translation activity. He draws on the concept of Snell-Hornby (1992) and Tytler, who rank among the basic principles of translation excellent knowledge of source and target language, knowledge of the translated material, ease of style and understanding of the content and form of the source text. Stolze (2008) claims that these principles inevitably lead to the need to use the hermeneutic method in translation.

Modern hermeneutic theories build on the concepts of a person's personal identity as a social construct constantly evolving in their linguistic activities and interaction with other participants, whether at the level of a community, a particular society, a wider culture, the whole lingua-culture, or intercultural and intercultural relations. Paul Ricoeur (1974, 1976, 1978, 1989, 1991a, 1991b, 2000) created an important conceptual basis for scholarly research of hermeneutic understanding as a human approach to social reality and the world. His hermeneutic theory, which is currently used in various interpretation disciplines, is widely applicable to translation research.

As already mentioned, his theory is based on the definition of man as being different from animals at the level of language (Ricoeur, 1989). Personal identity is thus conceptualized and structured in language, at the vague interface of semantics and pragmatics (1989). At the semantic level, personal identity is formed by a person saying the word $I$, which is associated with a particular name. At the pragmatic level, the meaning of the word $I$ becomes contextually dependent on the discourse within which it is continually formed. On the border between semantics and pragmatics, one becomes a reflexive Self capable of hermeneutic activity of understanding.

Ricoeur defines language as an objective system and/or code and discourse. He also argues that language as a code is of a collective nature, because it exists as a set of concurrent rules (synchronous system) and is anonymous in the sense that it is not the result of any intention. Language is nonconscious in terms of structural or cultural non-consciousness (Ricoeur, 1976). At the same time, discourse represents a temporal event in language and thus the realization of language. Discourse as an event in language has several characteristics. (1) Discourse always takes place at a particular time, in the present. Language is an object placed outside of time. (2) Discourse has a self-reference character, i.e. discourse refers to who speaks through several indicators, including personal pronouns. (3) Discourse always refers to something. Language, on the contrary, refers to signs that are placed within the same system. Discourse refers to a world that can be described. This is where language and discourse intersect, because discourse serves the language to become actual through it. (4) Participants in the discourse to which the discourse is addressed are also part of the discourse (Ricoeur, 1974). 
Language, in Ricoeur's view, cannot be reduced to unambiguous meanings, because it is in the language where ambiguity is reflected, and therefore approaching a language always requires hermeneutical interpretative activity, necessarily anticipating understanding [8, p. 33]. The necessity of hermeneutic activity within his theory results from the definition of language as a system of symbols, where the symbol represents "any structure of signification in which direct, primary and literal meaning denotes another meaning that is indirect, secondary, figurative, which can only be achieved by primary meaning" [9, p. 98]. Ricoeur also builds his hermeneutical definition of interpretation on the "assertion of thinking, which consists in decoding the hidden meaning in the apparent meaning and uncovering the levels of meaning contained in the literal meaning of the word" [9, p. 98]. The translation activity, which seeks not only to achieve equivalence but also to create a translation functional in the target lingua-culture, necessarily calls for the use of such a hermeneutic method that questions any primary meaning of a lexeme and leads to revealing secondary meanings of a particular expression in both the source and target languages. Drawing on the above mentioned it follows that that hermeneutic activity is present throughout whole translation activity and is not just its first stage, as Stolze (2011) suggests.

Interpretation as an essential part of the hermeneutic method represents a dynamic process incorporating a non-methodological moment of understanding and a methodological moment of explanation. Ricoeur describes this relationship as follows: "Understanding... precedes, accompanies, concludes and therefore surrounds the explanation. Explanation, on the other hand, develops understanding" [12, p. 142]. Therefore, although these moments are different from each other, they are also interconnected because they stand in a dialectical relationship. Interpretation cannot be reduced to one of them and therefore cannot stand alone. "Just as language, being brought to existence in discourse and performed as an event, discourse enters the process of understanding and becomes an event and meaning" (Ricoeur, [12, p. 78]). Interpretation is a significant aspect of the existence of man in contemporary society, which can be characterized for the presence of attempts to euphemize reality and for selective terminological inaccuracy with manipulative goals (Polačko, 2019).

In Ricoeur's theory, hermeneutic understanding is conceptualized as one of the essential determinations of man and so as a method by which man not only captures the conceptualized conceptosphere in the form of cognitive operations, but also is able to existentially reflect, understand and interpret the yet unthematized axiosphere.

Ricoeur's hermeneutic method consists of three stages, i.e. (1) prefiguration, (2) configuration, and (3) refiguration. The prefiguration stage is a phase of pre-understanding as implicit understanding of all networked relationships and structures of a particular cultural reality at all its levels. An individual at a given stage possesses a non-articulated knowledge of the society and culture, which they belong to and of the language in which they verbalize all meanings. This stage can also be described as the stage where an individual operates with all of their knowledge, pragmatic language and experience not yet structured to address one particular cognitive-reflective task. With regard to the thematic and nonthematic cognitive abilities of each individual, the translator, as a professional user of at least two languages, has cognitive-reflective knowledge in which at least two linguacultures interrelate and overlap. At the intralingual and interlingual levels of hermeneutic activity, it is necessary to point out that in the interpretation and understanding the individual not only uses the language but also changes and transforms it. As Taylor argues, language is not just a cluster of separable tools. Language is network-like and presents itself as a whole in each of its parts. People continually shape the language, stretch the boundaries of expression, create new terms, move the old ones, give the language a changed range of meanings (Taylor, 1985). The second stage of hermeneutic activity is the configuration stage, i.e. the stage of meaning conceptualization in language. The third stage, i.e. the stage of refiguration represents a full understanding of discourse and its interpretation. In the refiguration phase, the world of text and the world of the reader overlap (Ricoeur, 2000). Hermeneutic activity is fully executed in reading, which represents the space between pragmatics and semantic structure.

Ricoeur's hermeneutic method of understanding and interpreting the text represents a shift in translation theory in terms of directing attention to the concept of hermeneutic understanding and the 
analysis of the three stages of the hermeneutic interpretation process. However, with regard to examining possible approaches to translation and achieving optimal balance between equivalence in relation to the source text, functionality and adequacy of the translation, Ricoeur's theory has also weak points. Ricoeur argues that after writing the text, the author loses their control and a new relationship is established between the text and the reader in the process of appropriation. The text is open not only to an infinite number of readings, but also to infinite number of interpretations. Applying this approach to translation could also lead to a situation in which the meaning of the source text in the translation activity as an interpretative activity would be lost. Definitely, translation cannot become space of an unlimited number of interpretations. The borders of transfer of meaning and form on the one hand and the functionality and appropriateness of the target text limit translation creativity. For a translator, in order to achieve such a balance in their activity, hermeneutic activity is required throughout whole translation process and not only in its initial phase.

I my opinion, hermeneutic understanding activity is present throughout the translation process, which, however, takes place not only at the intralingual level but also in the interlingual space and therefore necessitates its revision to reflect the translator's membership in at least two different linguacultures.

\subsection{The Use of Hermeneutic-Pragmalinguistic Conceptualization Method in the Translation Process}

Based on the concept of the translator as a multilingual identity formed in the interlingual space during the translation activity and on the hermeneutic nature of this activity, a four-stage hermeneuticpragmalinguistic conceptualization method may be used in order to achieve the translation as an optimal result of this activity. The four-stage nature of this method and its structure are the result of team research in translatology, pragmalinguistics, cognitive linguistics, lexicography, hermeneutics, linguistic terminology and core linguistic disciplines ${ }^{1}$.

The main arguments for formulating the method of conceptualizing meaning in multilingual consciousness are the following ones: a) a man is a being, which conceptualizes meaning in language on intralingual and interlingual levels; (b) hermeneutic understanding involving a cognitive and existential aspect is an essential part of the conceptualization in the interlingual space; c) conceptualization is a culturally conventionalized and institutionalized principle of verbalizing meaning, and is distinctive for each particular lingua-culture. Drawing on the above-mentioned arguments as the theoretical basis of the translation process, any language unit (lexeme, sentence, syntactic structure, text) becomes a text unit as the subject of the hermeneutic method.

The proposed hermeneutic method, as defined in the previous research in which I participated (Bilá, Kačmárová, Vaňková 2017; Kačmárová, Bilá, Vaňková 2018), has the following structure within the translation activity:

1. establishing a cognitive framework;

2. encoding / preunderstanding;

3. salience as mentally preferred verbalization of meaning based on past experience;

4. code configuration.

Within the discussion on the conceptualization of the meaning in language, creators of framework semantics advocate the need to use a cognitive structuring tool allowing the use of differentiating criteria or an organizer of human experience to achieve conceptualization (Fillmore, 1985). Within this paradigm, the meaning comes from the experience schematization of the translator's language environment, which is based on their comprehensive experience and conscious epistemic and cognitive learning processes. It follows that the whole lexicon is organized in a certain and specific way through mental frameworks within which the semantic interconnection of individual lexemes is ensured based on their similarity and/or differences in their meaning and pragmatics (Fillmore, 1978). The translator

\footnotetext{
${ }^{1}$ The method was proposed within grant research task entitled Virtual interactive bilingual (English-Slovak-English) and encyclopedic dictionary of general linguistics.
} 
thus uses cognitive frameworks to allocate the meaning of a particular language unit to a particular semantic area. As stated in the study on the issue of translation of a selected type of linguistic landscape (Bilá, Vaňková, 2019), this stage represents a phase of identifying the function of the text, a target audience, a reader (cf. Nord, 2005) and topic(s). Only a reasonable understanding of the mental framework allows the translator to undertake an in-depth analysis of the source text.

Drawing on the aforementioned, translation activity must necessarily include a hermeneutic preunderstanding (Ricoeur, 2000), which is an essential initial phase of any cognitive and hermeneutic process. Within the translation activity, this role is played by pre-conceptual knowledge of the cultural and linguistic structural systems and codes of the respective source language and target language acquired through comprehensive experience, formal specialized education and lifelong career education. The concept of hermeneutic pre-understanding is based on the theory of human anchoring in language (Taylor, 1985), in which man, as a linguistic being, is able to articulate their experience and axiological conceptosphere (conventionalized and institutionalized concepts including morals) in the language. The articulation of human experience is the process of configuring meaning and its signification in the language. Conceptualization of meaning in the target language can be understood as a process of code creation aimed at the concept denotation. At this stage, a translator identifies a particular type of discourse and the subject of their translation activity, and on the basis of this identification further specifics of their work will be determined.

The third stage of the proposed structure is that of salience, i.e. verbalization of mentally preferred meaning based on previous experience and comprehensive knowledge. Giora (1997, In: Kačmárová, Bilá, Vaňková, 2018) argues that such preferred meanings are coded as conventional in the human mind. These favored meanings are dealt with automatically in a particular situation and are automatically processed based on previous experience and internalized comprehensive knowledge of a translator as well as on the translation and communication situation itself. This stage is possible if any particular experience becomes so preferred that it becomes dominant within a particular cognitive framework, then it is stored and retrieved whenever a verbalization of this meaning is needed. The more often a translator uses the preferred meaning, the more dominant it becomes within the relevant mental framework in the lexicon.

The phase of the meaning configuration in the target language completes the translation process as intercultural communication. In this phase, a translator implements the available translation strategies and uses appropriate translation solutions to verbalize the meanings in the target language, and then edits and posts the translation.

\section{CONCLUSIONS}

The use of the hermeneutic-pragmalinguistic conceptualization method in the translation process seems to be a solution for executing translation as intercultural communication. At the same time, it provides a tool for conducting translation at the level of lexemes, sentence and text. However, when using the proposed method, it should be added that its individual phases require the specification of the translator's work and the necessary hermeneutic-cognitive processes.

\section{REFERENCES}

[1] Bilá M., Kačmárová A., Vaňková I. What is behind the compiling of a dictionary for a bilingual user? In: Kieltyka R., Uberman A. (Eds.) Evolving nature of the English language: studies in theoretical and applied linguistics. Peter Lang, Franfurkt am Main, 2017, 201-209.

[2] Fillmore Ch.J. On the organization of semantic information in the lexicon. In: Frakas D. (Ed.) Papers from the Parasession on the Lexicon. Chicago Linguistic Society, Chicago, 1978, 148-173. 
[3] Fillmore Ch. J. Frames and the semantics of understanding. Quaderni di Semantica, 6 (2) (1985), 222-254. Avaible at: http://www.icsi.berkeley.edu/pubs/ai/framesand85.pdf

[4] Kačmárová A., Bilá M., Vaňková I. Conceptualizing of Conceptualization (of Linguistics Metalanguage). Prešov University, Prešov, 2018.

[5] Nord Ch. Text Analysis in Translation: Theory, Methodology, and Didactic Application of a Model for Translation-oriented Text Analysis. Rodopi, Amsterdam, New York, 2005.

[6] Polačko J. Etika ako predmet na vysokej škole vo vztahu k výzvam dnešnej post-faktickej doby [Ethics as a subject to the university in respect to the challenges of today post-factory time]. In: Vysokoškolská edukácia pre "digitálnu" spoločnost' a v "informačnej" spoločnosti. 1.čast' Informačno-komunikačné technológie a vysokoškolské vzdelávanie [University education for the "digital" society and the "information" society. Part 1. Information and communication technologies and higher education]. Technická univerzita v Košiciach, Košice, 2019, 49-65. (in Slovak)

[7] Ricoeur P. The Conflict of Interpretations. Essays in Hermeneutics. Northwestern University Press, 1974.

[8] Ricoeur P. Interpretation Theory: discourse and the surplus of meaning. Texas Christian University Press, Fort Worth, Texas, 1976.

[9] Ricoeur P. Existence and hermeneutics. In: Reagan C.E., Stewart D. The Philosophy of Paul Ricoeur: An Anthology of His Work. Beacon, Boston, 1978, 97-108.

[10] Ricoeur P. The human being as the subject matter of philosophy. In: Kemp T.P., Rasmussen D. (Eds.) The narrative path: the later works of Paul Ricoeur. Cambridge University Press, Cambridge, 1989, 89-101.

[11] Ricoeur P. From text to action: essays in hermeneutics. Northwestern University Press, Evanston, 1991.

[12] Ricoeur P. Life: a story in search of a narrator. In: Valdés M.J. (Ed.) A Ricoeur reader: reflection and imagination. University of Toronto Press, Toronto, 1991, 425-437.

[13] Ricoeu P. Čas vyprávění [Time and narrative], Vol. I. Oikomenh, Praha, 2000. (in Czech)

[14] Stolze R. The Translator' Approach: Introduction to Translational Hermeneutics: Theory and Examples from Practice. Frank \& Timme GmbH, 2011.

[15] Taylor Ch. Philosophical papers I.: Human Agency and Language. Cambridge University Press, Cambridge, 1985. doi: $10.1017 /$ СBO9781139173483

Address: Ingrida Vaňková, University of Prešov, 17. Novembra Street 1, 08005 Prešov, Slovakia.

E-mail: ingrida.vankova@unipo.sk

Received: 12.02 .2020 ; revised: 26.03 .2020 .

Ванкова Інгріда. Визнання та застосування герменевтичного методу у контексті дослідження перекладу. Журнал Прикарпатського університету імені Василя Стефаника, 7 (1) (2020), 207-213.

Дане дослідження зосереджено на застосуванні герменевтичного методу в перекладацькій діяльності. Розгляд проблеми опирається на вже сформовані концепції трансляційної герменевтики, які розглядають цей метод як частину початкової фази перекдадацької діядьності. Однак у дослідженні представлений підхід, згідно з яким герменевтична активність присутня протягом усього процесу перекладу. Автор розглядає розгортання герменевтичної концепції Рікера в інтерпретації та розумінні на складній перекладацькій діяльності. Нарешті, новий герменевтико-прагмалінгвістичний метод концептуалізації впроваджується із застосуванням герменевтичного підходу в рамках складного процесу перекдаду. Відзначається, що на смисловому рівні особистісна ідентичність формується дюдиною, яка вимовляє слово I, яка асоціюється з певним іменем. На прагматичному рівні значення слова I стає контекстно залежним від дискурсу, в якому воно постійно формується. На межі між семантикою та прагматикою дюдина стає рефлексивним Я, здатним до герменевтичної діяльності розуміння. Автор акцентує увагу на дослідженнях Рікера, який визначає мову як об'єктивну 
систему та / або код і дискурс. Він також стверджує, що мова як код має колективний характер, оскільки існує як сукупність паралельних правил (синхронна система) і є анонімною в тому сенсі, що вона не є результатом будь-якого наміру. Мова не усвідомлена 3 погляду структурної чи культурної несвідомості. Описано етапи герменевтичної діяльності. Вказано, що на першому етапі розкривається сутність інтерпретації як важливої частини герменевтичного методу, який явдяє собою динамічний процес, що включає неметодологічний момент розуміння та методологічний момент пояснення. Другий етап герменевтичної діяльності - етап конфігурації, тобто стадія концептуалізації сенсу в мові. Третя стадія, тобто стадія рефігурації, - повне розуміння дискурсу та його інтерпретації.

Обгрунтовано, що герменевтична діяльність повністю реалізуеться в читанні, що представляє простір між прагматикою та семантичною структурою. Цей етап описується як етап, коли людина оперує усіма своїми знаннями, прагматичною мовою та досвідом, ще не структурованими для вирішення одного конкретного когнітивно-рефлексивного завдання. Що стосується тематичних та нетематичних пізнавальних здібностей кожної людини, то перекладач, як професійний користувач щонайменше двох мов, має когнітивно-рефлексивні знання, в яких принаймні дві мовні культури взаємозв'язуються та перетинаються. Доведено, що на внутрішньомовному та міжмовному рівнях герменевтичної діяльності (в інтерпретації та розумінні) індивід не лише використовує мову, а й змінюе та перетворює їі.

Ключові слова: дискурс, герменевтика, інтерпретація, текст, переклад, герменевтикопрагмалінгвістична концептуалізація. 